\title{
The Master's Race: Phallic Whiteness in "The Young Savages"
}

\author{
Graham Cassano
}

This essay examines two parallel, historically contemporaneous, depictions of the Freudian master-slave dialectic. John Frankenheimer's first film, The Young Savages (1961), reconstructs Hank Bell's (Burt Lancaster) repressed transformation from Italian racial other into a white ethnic. In doing so, the film approaches the possibility that race itself may be a kind of social construction. To get at this notion, the film explores the meaning of race in an overtly psychoanalytic language. In fact, The Young Savages echoes the argument of Jacques Lacan's nearly contemporaneous essay, "The subversion of the subject and the dialectic of desire in the Freudian unconscious." Lacan's paper, first delivered in 1960, and Frankhenheimer's film, argue that the normatively socialized subject must sacrifice an essential part of themselves in order to achieve social recognition. In Lacan's language, every subject is castrated, and because of that mutilation, every subject desires completion through the symbolic phallus. To accept castration, and to desire the phallus, is to live under the dominion of the name-of-the-father. Hank Bell enters into this dialectic of desire, discovers his own lack (the history of his repressed racial identity), as well as his desire for the phallus (whiteness). In short, the film allows for an understanding of Lacan's dialectic as the unfolding of normative white supremacy, and Lacan allows for an understanding of the film as a dialectic of desire. At the same time, both Lacan's essay, and The Young Savages share the same fundamental aporia. For Lacan, the phallus is not a penis, but a structural position; nonetheless, rather than renaming the phallus as male domination, Lacan leaves the phallic language in place, unquestioned. Even as Lacan opens a path to the interrogation of masculine domination, he essentializes patriarchal language, and paradoxically takes refuge in a developmental argument to ground the significance of the phallus as a symbol. In the same manner, The Young Savages questions the concept of whiteness, recognizes race as a social construction, but pulls back from that recognition, and ultimately leaves the normative racial order intact. ${ }^{1}$

\section{Introduction}

Between 1886 and 1925, 13 million new immigrants came to the United States from Southern, Central, and Eastern Europe. ${ }^{2}$ On the one hand, many of these new immigrants were recognized as legally "white," in the sense that they were considered fit for naturalization, unlike immigrants from Asia or Africa. ${ }^{3}$ On the other, many were considered unfit for whiteness by custom, nativist prejudice, anti-Catholicism, and anti-Semitism. According to David Roediger, these "in-between-peoples" evaded the hard color line that confronted Black Americans, First Peoples, and Asian immigrants; but did not necessarily find full acceptance within the normatively white community. By the mid-twentieth century, racial boundaries had shifted. ${ }^{4}$ Italian Americans, Jewish Americans, Bohemian, Russian, and Czech Americans, became "ethnic" whites. At the same time, assimilation to whiteness had a price. These new immigrants, their children, and grandchildren needed to accept the demands of white supremacy, and thus to identify with anti-Black, anti-Asian, anti-Latina/o prejudices. In addition, they had to repress their own ethnic identity and to desire the trappings of what they imagined was the fully "white" lifestyle. Cinema dramatized this play of racial desire. From Black Fury (1935) to Fort Apache (1948), a process unfolds in which immigrants find a home in the U.S. 
once they accept white supremacy and valorize white racial identity. ${ }^{5}$

Racial transformation requires a kind of socially constructed amnesia. As families cross into whiteness, they actively forget their prior racial status. This chapter examines the traces left once such a racial trans-substantiation has taken place. John Frankenheimer's early film, The Young Savages (1961), reconstructs Hank Bell's (Burt Lancaster) repressed transformation from Italian racial other into a white ethnic. In doing so, the film approaches the possibility that race itself may be a kind of social construction. To get at this notion, the film explores the meaning of race in an overtly psychoanalytic language. In fact, The Young Savages echoes the argument of Jacques Lacan's nearly contemporaneous essay, "The subversion of the subject and the dialectic of desire in the Freudian unconscious." Lacan's paper, first delivered in 1960, and Frankhenheimer's film, argue that the normatively socialized subject must sacrifice an essential part of themselves in order to achieve social recognition. In Lacan's language, every subject is castrated, and because of that mutilation, every subject desires completion through the symbolic phallus. To accept castration, and to desire the phallus, is to live under the dominion of the name-of-the-father. Hank Bell enters into this dialectic of desire, discovers his own lack (the history of his repressed racial identity), as well as his desire for the phallus (whiteness). In short, the film allows for an understanding of Lacan's dialectic as the unfolding of normative white supremacy, and Lacan allows for an understanding of the film as a dialectic of desire.

At the same time, both Lacan's essay and The Young Savages, share the same fundamental aporia. For Lacan, the phallus is not a penis, but a structural position; nonetheless, rather than renaming the phallus as male domination, Lacan leaves the phallic language in place, unquestioned. Even as Lacan opens a path to the interrogation of masculine domination, he essentializes patriarchal language, and paradoxically takes refuge in a developmental argument to ground the significance of the phallus as a symbol. In the same manner, The Young Savages questions the concept of whiteness, recognizes race as a social construction, but pulls back from that recognition, and ultimately leaves the normative racial order intact. I will argue in the conclusion of this paper that Lacan's insistence on phallic language represents an anxious evasion of the work of Simone de Beauvoir, but also, less obviously, of Frantz Fanon. Unlike Lacan, Fanon argued that through a shudder of violence, the old order could shatter. Lacan's reification of the phallus represented his anxious turn away from that possibility. In the same manner, The Young Savages attempts to tell the story of race, and yet entirely represses the most important social movement of its time, the African American led civil rights movement. Like Lacan's essay, the film avoids anxiety-provoking questions about race in America by turning itself into a valorization of the very whiteness it questions.

\section{Lacan's Phallus}

Systems of domination perpetuate themselves in multiple forms. They are social facts inscribed upon the bodily habitus of the dominated. They are modes of knowledge, epistemological practices, and ways of seeing that separate "insiders" from "outsiders." They are material classifications that mediate an unequal distribution of wealth and status within society. What all forms of symbolic and material domination have in common is the need for legitimacy. In order to function, systems of domination require the consent of the dominated. They achieve consent through various mechanisms. Through terror. Through material coercion. Moreover, through the use of hegemonic coordinates of desire. In order to secure authority over its subjects, domination imposes, brutalizes, bribes; but it also seduces.

Charles Horton Cooley's discussion of the "looking glass self" attempts to explain the social force of seduction. For Cooley, the subject emerges into consciousness through the gaze of the other. Put in more developmental terms, the biological infant becomes a socialized child by accepting the judgments, attitudes, and points of view imposed by caregivers. The language the child acquires comes from others. Its values and beliefs originated with others. Finally, its sense of propriety, shame, guilt, and pride, come from its own imagination of the other's point of view.

The reference to other persons involved in the self of the self may be distinct and particular, as when a boy is ashamed to have his mother catch him at something she has forbidden, or it may be vague and general, as when one is ashamed to do something which only his conscience, expressing his sense of social responsibility, detects and disapproves; but it is always there. There is no sense of "I," as in pride or shame, without its correlative sense of you, or he, or they.

Socialization means coming to see oneself through the perspective of others. This basic proposition, however, contains a number of implied corollaries. First, since the subject sees itself through the (metaphorical) eyes of the 
other, it knows itself primarily based upon this other's point of view. The self thus has no privileged access to itself. Further, to the degree that the subject seeks self-approval, it seeks the approbation of the other. That is, the other's judgment shapes the subject's consciousness. Therefore, the subject seeks the other's recognition (as this or that kind of subject) in order to come to know itself. In more Lacanian language, desire desires the others desire. For Cooley, that means that the social subject who desires normative approval (in order to approve of itself), takes on the social practices of prestigious others (caregivers, educators, ministers, political leaders, bosses) in order to gain their approbation. The subject's desire for the other's desire thus has at least two pathways: First, the subject desires the other's recognition (e.g., desire); second, the subject desires the same norms, ideas, commodities, that the other desires, in order to gain that recognition. Customs, beliefs, and attitudes spread through a society based upon this desire to gain the other's imagined approbation.

While Cooley never fully examines the implications of the decentered subjectivity he describes, in the European context, Alexander Kojeve and Jacques Lacan, students of Hegel and Freud, develop a parallel but more complex dialectic of desire. Like Cooley, Kojeve situates the subject as a social product of the other's desire. ${ }^{9}$ Desire is always directed toward the other's desire. "Desire is human only if the one desires...be 'desired' or 'loved,' or... 'recognized' in his human value, in his reality as a human individual." ${ }^{10}$ Human reality "can be begotten and preserved only as 'recognized' reality. It is only by being 'recognized' by another, by many others, or-in the extreme---by all others, that a human being is really human, for himself as well as for others." ${ }^{11}$ As with Cooley, the subject recognizes itself in the gaze of the other, understands itself based upon the actions, reactions, and behaviors of the other. Thus, in its search for itself, the subject seeks the other's recognition. However, in order to achieve this recognition, it enters into a metaphorical contest, Hegel's Master-Slave dialectic. ${ }^{12}$

Following closely the argument presented by the Phenomenology, Kojeve begins with two absolute subjects, each one desiring confirmation of its own self-image through recognition from the other. At the same time, neither desires "mutual and reciprocal" recognition. Each expects sovereignty. Recognition depends upon the adversary's defeat. The Master and the Slave make one another. "The Slave is the defeated adversary... Hence, he depends upon that other... The Master is Consciousness existing for itself."14 Losing this "fight for pure prestige," the Slave "recognizes the master in his human dignity... [and] behaves accordingly."15

To return to Cooley's initial description of socialization, the Slave represents the socialized subject, accepting the Master's discourse, and recognizing the Master's authority. The Master takes possession of the Slave. "For everything that the Slave does is, properly speaking, an activity of the Master. Since the Slave works only for the Master, only to satisfy the Master's desire and not his own, it is the Master's desire that acts in and through the Slave."16 The Slave becomes the instrument of the Master's desire, just as a socialized subject serves the norms of their community, and obeys the laws, customs, and practices, of their people.

But the Master's victory is empty. "For he can be satisfied only by recognition from one whom he recognizes as worthy of recognizing him." While this dialectic initially reifies the Slave, transforming it into an instrument of the Master's will, the slave's defeat becomes victory. Because the Master appears worthy of respect, the Slave becomes human by imposing itself "on the Master," and thus being "recognized by him." ${ }^{17}$ This potential reversal becomes possible precisely because "The Master forces the Slave to work." Through work, "the Slave becomes master of Nature," and thus, "frees himself from his own nature."18 The Slave comes to recognize its power, and thus sheds the need for a Master. Through work in the world, the Slave transcends mastery and servitude.

Thus, through the mediating power of the other's gaze, the subject moves from sense certainty, through slavery, into self-knowledge. Written after Marx and after Freud, Kojeve's interpretation of Hegel already anticipates Lacan's psychoanalytic redirection. The self is both Master and Slave. But Lacan rejects the dialectical resolution to the Master-Slave struggle. Such a resolution necessarily misses its mark by seeking the reality of an ego that is only ever an illusion, or meconnaisance. "What is this real, if not a subject fulfilled in his identity to himself." 19 Lacan retains the dialectic of desire but dispenses with Hegel's idealism. "There is nothing, then, in our expedient for situating Freud...that proceeds... from any phenomenology from which idealism may draw reassurance." ${ }^{20}$ The reference here is most obviously to philosophical idealism, but, the text extends the meaning to cover the idealism of the activist, the resister, and the revolutionary. In fact, Lacan argues that if the task of the revolutionary is to overturn the Law, they fail before they begin. From the Lacanian perspective, revolutionism is an infantile disorder.

Let me take these two forms of idealism in turn since they structure the remaining portions of Lacan's argument. First, the philosophical idealism that posits a subject who transcends the master-slave dialectic. A "gap...separates those two relations of the subject to knowledge, the Freudian and the Hegelian." This gap emerges from Hegel's unwillingness to follow through the implications of his theory of desire. "Hegel's 'cunning of reason' means that, 
from beginning to end, the subject knows what he wants." In contrast, "Freud reopens the junction between truth and knowledge" by interrogating the process in which "desire becomes bound up with the desire of the Other." 21

The Slave desires the Master's desire, and the Slave becomes the instrument of that desire. In this sense, Hegel attempts to break with the Cartesian subject. The Cartesian subject is an "I," inhabiting a knowable world. Hegel's Slave is a "we," inhabited by itself, but also, by an Other. This Other shapes and controls the subject's desires, the subject's knowledge, and the subject's self-reflections. While the Cartesian subject might come to know itself through thought, and perhaps even through activity in the world, the Hegelian subject divided by alterity never fully knows the Other who inhabits it--that is, until the dialectic is resolved. But, Lacan argues, this dialectic has no resolution. He offers an ancient allegory as an illustration. The subject is

like the 'messenger-slave' of ancient usage, the subject who carries under his hair the codicil that condemns him to death knows neither the meaning nor the text, nor in what language it is written, nor even that it had been tattooed on his shave scalp while he slept. ${ }^{22}$

If the subject is inhabited by others, it can never fully grasp the contours of these Outsiders within. Instead, it is perpetually inscribed with an indecipherable otherness, and driven by a necessarily incomprehensible desire. Lacan's radical difference with Hegel and Kojeve emerges from two fundamental Freudian concepts: identification and ambivalence. Freud attempts an explanation of both in his (gendered and patriarchal) account of the Oedipus complex.

Identification is known to psycho-analysis as the earliest expression of an emotional tie with another person. It plays a part in the early history of the Oedipus complex. A little boy will exhibit a special interest in his father; he would like to grow like him and be like him, and take his place everywhere. We may simply say that he takes his father as an ideal. ...At the same time as this identification with his father...the boy has begun to develop a true object-cathexis towards his mother... ${ }^{23}$

As with Cooley's "looking glass self," the subject emerges as a social being through processes of identification and attachment. Recognition comes into play to the extent that the boy wishes, through identification, to be recognized as a simulacrum of his father. But identification transforms the father, idealizing him into a symbol (the Other's desire). The boy desires the father's desire, his father's recognition. In order to achieve that recognition, he attempts to become what he imagines father to be. That means he wishes to replace the father for his mother. The unconscious understands that this identification is the equivalent of patricide and that desiring mother will invoke the symbolic father's rage. Thus this symbolic father, as an ideal, desires to punish the boy for desiring the mother, and for desiring father's death. Consequently, the boy, who desires the father's desire, desires his own punishment and fears the complexity of his desire. Freud names this complexity "ambivalence."

The little boy notices that his father stands in his way with his mother. His identification with his father then takes on a hostile colouring and becomes identical with the wish to replace his father in regard to his mother as well. Identification is, in fact, ambivalent from the very first... ${ }^{24}$

The boy's desire for his father's desire is mingled with his fear and hatred of the punishing other. And the boy's own love for himself is shaped in part by the stern judgment of this punishing father. The boy hates himself and wishes to be punished, even as he desires love and approbation.

Love and attachment produce identification, which is necessarily ambivalent. The Other is loved and hated, desired, and feared. To the extent that the Other inhabits the subject, those forces turn inward. The Other becomes the subject's sadistic master. For Lacan, this Other both inhabits the subject and yet remains perpetually distant and dissatisfied, thus producing the "subjection of the subject to the signifier...for lack of an act in which it would find its certainty..." Attachment and identification are the forces of socialization. However, in identifying with this symbolic father, the subject emerges as a permanent slave, instrument of a cruel Master's desire.

The Other as previous site of the pure subject of the signifier holds the master position... For what is omitted in the platitude of modern information theory is the fact that one can speak of code only if it is already the code of the Other, and that is something quite different from what is in question in the message, since it is from this code that the subject is constituted, which means that it is from the Other that the subject receives even the message he emits. ${ }^{26}$

In a deft intellectual maneuver, Lacan moves from a subject inhabited by an unknowable, sadistic otherness, through the identification with other social subjects as objects of desire, and thus, emulation, to the internalization 
of a normative code that speaks through the subject. Despite Lacan's dislike of Emile Durkheim's ideas, the Master's code reads remarkably like Durkheim's description of social facts.

When I perform my duties as a brother, a husband, or a citizen...I fulfill obligations which are defined in law and custom and which are external to myself and my actions....The system of signs that I employ to express my thoughts, the monetary system I use to pay my debts, ...the practices I follow in my profession, etc., all function independently of the use I make of them. ...Thus there are ways of acting, thinking and feeling which possess the remarkable property of existing outside the consciousness of the individual. ${ }^{27}$

For Durkheim, as for Lacan after him, the socialized subject is possessed by the discourse of dead others. Language, custom, and norm, speak through the self. But for Lacan, it is, specifically, the dead father who speaks. ${ }^{28}$ When the subject identifies with an idealized, symbolic father, it reifies that identification into the "Name-of-theFather," Lacan's allegory for the socially constituted set of norms, he calls "the Law." 29 Through identification (specifically with the Name-of-the-Father), the "symbolic dominates the imaginary." 30 This dominance of the symbolic over the real and the imaginary secures its force through the father's reified emblem, the phallus.

Although never mentioned by name, Simone de Beauvoir is the hidden presence in "The subversion of the subject." According to de Beauvoir, Freud

assumes that a woman feels like a mutilated man; but the notion of mutilation implies comparison and valorization.... the fact that feminine desire is focused on a sovereign being gives it a unique character; but the girl is not constitutive of her object, she submits to it. The father's sovereignty is a fact of social order: Freud fails to account for this... ${ }^{31}$

De Beauvoir's critique of Freud is devastating because she critiques Freud from within, and repeatedly charges him with failing to answer (or answer fully) questions that his own work provokes. He takes for granted what he should be able to account for. Precisely because of the irresistible force of de Beauvoir's critique, Lacan tries to account for what Freud took for granted, the significance of the phallus. While, symptomatically, he never mentions The Second Sex, Lacan incorporates de Beauvoir's insight that "The father's sovereignty is a fact of the social order." At the same time, Lacan's attempt to resurrect the castration complex returns us to his attack upon idealism that draws comfort from dialectics. His argument for the necessarily phallic character of the Law becomes an argument against revolutionary change.

Lacan addresses the gendered character of his schema, and by implication, the patriarchal language of Freud's description of the Oedipus complex. "The fact that the Father may be regarded as the original representative of this authority of the Law requires us to specify by what privileged mode of presence he is sustained beyond the subject who is actually led to occupy the place of the Other, namely, the Mother." 32 Returning to a much earlier argument, Lacan posits a developmental sequence of socialization in which identification with the symbolic Name-of-theFather supplants an original (and imaginary) identification with the mother. As Freud argues in his account of the Oedipus complex, this identification with the symbolic/social Father requires castration. In order to take the place of the Father, the little boy must accept the Father's judgment. Thus, Lacan argues, the Oedipus complex may be a myth, "But what is not a myth, and which Freud nevertheless formulated soon after the Oedipus complex, is the castration complex." 33

Society castrates every subject (male and female), in the sense that all lack the symbolic phallus that is the emblem of the Law. This phallus thus becomes the icon of the Other's desire. It is a jouissance (fulfillment) that is perpetually out of reach. Because the subject desires the Other's desire, and thus to take the Other's place, the subject desires the Other's phallus. In order to achieve the Other's recognition, "the subject here makes himself the instrument of the Other's jouissance." 34 As with Kojeve-Hegel, the Slave becomes the Master's instrument. But this instrumentality does not prefigure freedom. Instead, the slave pursues the Master's pleasure, for the sake of the Master, and infinitely defers its own desires. Jouissance, or fulfillment, only belongs to the Master. Thus, the Slave endlessly chases what it will never achieve, the Master's recognition.

Lacan's description of desire accounts for the ordinary obedience of the vast majority of social subjects living in authoritarian conditions. But Lacan never fully explains why the phallus becomes the valorized mediator of all desire under the Law. He could have argued that in a society dominated by men and by patriarchal traditions, mores, and everyday practices, the phallus becomes a symbolic metonym of male power. This was de Beauvoir's argument. But he does not. Indeed, as de Beauvoir says of Freud, Lacan continues to assume what he should explain. As a student of semiotics, he was always quick to point out the contingencies inherent in all signification. Yet his few attempts to justify this symbology on developmental grounds are hardly convincing. In the mirror stage, he argues, 
the subject is captivated by an imaginary construction that misperceives the reality of the infant's dependence. This meconnaisance situates the subject's ego in a perpetually fictional direction. During this process, "the image of the penis... [as] negativity in its place in the specular image...is what predestines the phallus to embody jouissance in the dialectic desire." 35

In order to understand Lacan's reification and seeming essentialization of terms like "phallus" and "name-ofthe-father," consider, again, his attack upon idealism inspired by dialectics. While Lacan may have been sympathetic to certain structuralist variants of Marxism, he seems to suggest that revolution, as the absolutely Hegelian contest with the other, represents a Lost Cause.

To whomsoever really wishes to confront this Other, there opens up the way of experiencing not only his demand, but also his will. And then: either to realize oneself as object, to turn oneself into a mummy, as in some Buddhist initiation rites, or to satisfy the will to castration inscribed in the Other, which culminates in the supreme narcissism of the Lost Cause... Castration means that jouissance must be refused, so that it can be reached on the inverted ladder of the Law of desire. ${ }^{36}$

Lacan naturalized the phallus as a symbol of social power; he naturalized male domination in the form of the Law and the Name-of-the-Father; he did so, even as he had the theoretical tools to explore the social structures of domination that inhabited those words. From a psychoanalytic perspective, it would seem that Lacan pulled away from his own insights; that a certain anxiety provoked his phallic language. Perhaps his was simply a failure of (theoretical) imagination. But I think it was more than that. I think Lacan could imagine alternatives, and that provoked repression.

Further, while Lacan was threatened by the existentialism represented by Sartre and de Beauvoir, he was not so threatened as to entirely repress their presence in his work. Sartre is named often as a respondent, and it does not take much excavation to find de Beauvoir as the more or less conscious object of Lacan's arguments about the symbolic phallus. But I suspect there is another, far more threatening presence in Lacan's argument against the revolutionary transformation of the social order. The very fact that Lacan never mentions Frantz Fanon, at least nowhere in Ecrits, suggest that Fanon represents the real threat to the Name-of-the-Father and that decolonization is the actual object of Lacan's phallic arguments. I will return to this fear of the wretched of the earth after a detour through a film that seems to be an unconscious adaptation of Lacan's essay, Frankenheimer's The Young Savages.

\section{The Young Savages}

Let me begin my discussion of The Young Savages with a synthetic synopsis. The film is a courtroom drama, in the sense that it ends with a climatic courtroom scene. But much of the picture unfolds in poor immigrant neighborhoods, and in spaces reserved for the New York elite (high rise apartments, well-appointed offices). It begins with the premeditated murder of a blind Puerto Rican teenager on his tenement stoop by three members of an Italian (and, presumably, Irish) gang, the Thunderbirds. A politically ambitious District Attorney assigns Hank Bell (Burt Lancaster) to prosecute the case. As the narrative progresses, a series of sub-narratives and flashbacks (from gang leaders, mothers, and neighborhood residents) complicate what at first appears to be a simple case. The first complication is Bell himself. While he lives in an expensive high-rise apartment, has a seemingly perfect blonde wife, and an obedient, poised daughter, the audience learns quickly that he came from Italian Harlem, and that his family name was originally 'Bellini.' At the same moment, the film also reveals that one of the young killers, Danny Dipace, is the son of Hank's old sweetheart from the neighborhood, Mary (Shelley Winters). The reels that follow these first revelations dramatize Hank's struggle with his conscience, and his wife, Karin (Dina Merrill), as he prepares the murder case. Throughout the film, when Karin pleads for the boys, Hank dismisses her, referring to her Vassar education ("here we go with the Vassar theories of social oppression"). Yet through Karin's arguments, and through his reconnection with Mary, Hank begins to rediscover his past, or, more correctly, to recognize the way in which his ambitions and success have caused him to repress his past. This return of the repressed leads Hank to a further recognition: he identifies the social construction of whiteness, and his own participation in that social construction; and, further, he recognizes that his passage to whiteness was mediated by his marriage to the unambiguously Anglo Karin. This recognition allows Hank to acknowledge his identification with the three murderous boys. Consequently, he intentionally sabotages his case. While they do not walk free, none face the consequences of first-degree murder (the electric chair). 
At the same time, another parallel narrative explores the perspectives of the gang leaders, the Italian socio-path, Pretty Boy Savarisi, and the ambitious, charismatic, and intelligent Puerto Rican leader of the Horsemen, Zorro. The representation of Zorro creates central contradictions for the narrative. Unlike Pretty Boy, Zorro is not a sociopath. Indeed, he seems to have a clear understanding of the history of immigrant whiteness in the United States, as well as of the repressed cultural contributions of Spanish speaking peoples. Moreover, in a pivotal scene where Bell meets Zorro at home, the latter's tenement rooms have the stereotypical look of Jewish or Italian immigrants photographed by Joseph Riis. There is even an old woman in the foreground doing piece work in the central room. Zorro never demands more than justice, even as he understands that brown-skinned peoples don't receive justice in the U.S. Thus, the film, while clearly told from Hank Bell's point of view, also contains a meta-narrative about immigrants, race, and (in)justice. This meta-narrative competes with Hank's perspective and creates unconscious tensions. Even Bell sees the limitations in the outcome. When the film ends with the confrontation between the blind boy's mother and Bell, he responds to her plea for justice by saying, "A lot of people killed your son, Mrs. Escalante."

Thus, when Hank Bell comes to reflect upon and understand his transition into whiteness, it leads him to form an identification with those left behind. But it does not cause him to fundamentally question whiteness itself. As I will demonstrate below, the film depicts Hank's inclusion as a member of the white race as a castration in which he sacrifices his potential identification with other, non-white, communities, even as he is allowed to re-create himself through a "symbolic ethnicity" the knits together his past and present. In this sense, and not in this sense only, The Young Savages echoes the argument Lacan makes in "The subversion of the subject." Just as Lacan remains unwilling to relinquish the language of the castration complex, so too, the film deconstructs the question of race, and then anxiously pulls back from its own knowledge, finally reifying the racial categories it questioned.

\section{Recognition}

Throughout the narrative, the film projects a racial liberalism, equating the struggles of the descendants of the "new immigrants" from the 1890-1924 generation with the struggles faced by the newest generation of Puerto Rican Americans. Zorro understands these parallels. In an exchange that both underscores the gang leader's brutal authority and humanizes his character, Zorro explains the racialized order of the streets to Bell. About the Thunderbirds, "the others are bad, but they're the worst."

"You don't like 'em do you? Any of them." asks Bell.

Zorro hears "any of them" as a reference to the other racial and ethnic enclaves surrounding his 'territory.' "Well, man, put yourself in my shoes!" He starts counting on his fingers. "The niggers look down on us. The wops look down on us. The Irish were here before the Indians. Man," he puts his hand on his heart, "my people are a proud race. Puerto Rico ain't no African Jungle. And the wops, what did they ever have? Mussolini? A big stink. Michaelangelo? So what. You ever hear of a guy named Picasso? Pablo Picasso, man. I went all the way down to a museum to look at his paintings. Now that cat is great. The greatest artist who ever lived, man, he sings, and you know..." Zorro trails off as he is interrupted by one of his lieutenants, and together they step outside to beat a delivery boy late on his protection payments.

Zorro's racial soliloquy demonstrates that while racial liberalism may be an option for third-generation Vassar girls and second-generation Italian Americans, new arrivals learn the hard edges of American racial hierarchy from the ground up. Race is a social fact, with real boundaries and affects. But at the very moment that Zorro recognizes the social fact of race, he also recognizes its malleability. "The Irish were here before the Indians..." suggests that social status and racial classifications change over time. "And the Wops, what did they ever have?" As the most recent immigrant group to "become white," Zorro challenges Italian racial status precisely in order to assert his own claim to full American-ness, e.g. to whiteness. Yet even as he challenges racial oppression, for his group, he uncritically accepts other forms of racism ("Puerto Rico ain't no African jungle").

Moreover, in the sequence that follows, Zorro reveals the force behind this desire for full citizenship in a white republic. "We got three square blocks here, and we're busting to get out... But while we're here...people got to respect us." When he tells Bell that the money he took from the delivery boy isn't "the point," he emphasizes, once more, that what matters is respect. What Zorro seeks is recognition. What he desires is the other's desire. And, in a white republic, that desire is itself shaped by normative racial and physical boundaries ("three square blocks") that imprison those on the outside of white. 


\section{| Phalluses}

At the beginning of the second act, the film reveals its psychoanalytic orientation. The scene opens with a courtappointed psychiatrist on the telephone. Speaking to a disembodied other, he says "I don't want you to run another Rorschach. ---I don't care if he's faking.---I don't care! What he's faking reveals just as much as his real reactions...” At that point, Hank barges into the office. In all likelihood, it's an accident of history that the doctor's voice echoes Lacan's attempt to distinguish animals from human beings. "But an animal does not pretend to pretend. He does not make tracks whose deception lies in the fact that they will be taken as false, while being in fact true ones, ones, that is, that indicate his own trail." ${ }^{37}$ Nonetheless, the film represents the psychiatric/psychoanalytic perspective as the path to the "truth" that Hank pretends to seek throughout the film. While the film does not reveal this perspective immediately, from the first sequence on, it puts psychoanalytic techniques of representation to work.

From the film's perspective, the materialized symbolic phallus (the knife, the cane, the pool cue, the harmonica) represents those outside the Law. ${ }^{38}$ These materialized emblems are "transitional objects" signifying the subject's fixation upon the image of the phallus, rather than the symbol of the Law. In Lacan's terminology, these phallic substitutes signify the fixation on the mirror-stage. That is to say, these subjects remain captive to an imaginary meconnaissance that prevents their full recognition of the Law. They are members of communities, but not members of the Community. They have not accepted the Name-of-the-Father. Instead, they are a band of primal brothers, unable to achieve full status as Law-abiding citizens.

The film's first shot: the blind boy, Roberto Escalante, playing solo harmonica beside his sister, an idyllic scene that shifts to a plain brick wall. Then, as the camera moves, the brick wall becomes Thunderbird's territory, marked out by their emblem in paint. Three young men in leather jackets march toward the camera. The harmonica fades away and there are a few moments of silence as the boys march into the light. An orchestral jazz score inflected with Latin percussion announces their ominous intentions. The continuous tracking shot takes us through the streets of Italian Harlem, toward "Little Puerto Rico," until the musical climax, then cuts to a shot of the backs of three leather jackets, and three arms simultaneously pulling switchblades from their belts. The camera shows their reflection in the blind boy's dark glasses as they stab. The camera cuts to his broken glasses on the ground reflecting the boy, arms outstretched, his sister attending his dead body.

While the Thunderbirds remain ciphers throughout the picture, and the precise motivation for the murder is never fully revealed, the stakes involved in the struggle between the gangs is very clear. As Zorro tells Bell after shaking down a delivery boy, "it ain't even about the money. It's about respect." What all the gangsters want is respect, the recognition of the other. But rather than seek that recognition from the Law, they seek it from each other. They are locked in poverty, the film argues, in part because they are locked in this struggle between one another. They cannot see what they have in common; nor can they accept their common subservience in the face of the Law. Hank, however, stands above this contest. The film shows that he is tri-lingual, speaking Italian, Spanish, and English with seeming fluency. He is a mediator.

Once again, this futile struggle over transitional objects is marked by materialized symbols. The switchblades are transitional objects representing the penises the boys cannot admit they've lost. Nor is this metonymic connection between switchblades and penises simply an interpretive imposition. The film announces the connection quite clearly. At one point, a police lieutenant's phone call wakes Hank. The lost murder weapons, the knives, have been found. When Bell, angry, asks the lieutenant, "What could I possibly do with them at this hour of the night?" the cop responds "Want a suggestion?" thereby solidifying the connection between knife and penis. The film carries this symbolism further. Both gang leaders also hold phalluses in their hands. Pretty Boy Savarisi fondles a pool que during his conversation with Bell, while Zorro carries a cane (presumably with a blade inside) as an emblem of his power. In addition, the film establishes an equivalency between the blind boy's harmonica and the murderers' blades (they all glint in the sun).

In the climactic courtroom scene, Bell's final act of sabotage is to exonerate Danny Dipace. Lab reports show that one of the three knives used in the conspiracy had no blood. Bell wants to connect Danny to that knife, thereby demonstrate Danny's relative innocence. As he badgers the boy, he continually waves the knife in Danny's face. Bell holds Danny's symbolic penis in his hand, but, simultaneously, appears to threaten Danny's castration using that very penis. As the accused breaks down into tears, he declares, guiltily, his innocence, that he did not stab Roberto

Escalante. This admission represents a break with his gangster community, and, through castration, and his one-year sentence in juvenile detention, a path toward acceptance of the Law. 


\section{Mirrors}

In addition to metonymic phalluses, the film plays with mirrors in ways that reveal meaning. I've already mentioned the blind boy's glasses. They prefigure a repeated theme. When a group of Thunderbirds threatens Karin Bell in her apartment elevator, one of the boy's looks beyond her, into the elevator mirror, and combs his hair, as the other opens his switchblade. That is, one is fixated by his own imaginary reflection, while the other, again, compensates for his unacknowledged castration with a materialized symbol of what he lost. Another scene, in tenement rooms, has Zorro plead his case for justice as he looks for a few moments into the mirror, and like the Thunderbird, combs his hair. Once again, the stake is recognition. Here the boys look into the mirror, seeking recognition from the misperception that stares back. They want to be seen as this or that, as hard, as solid, as fixed things. The mirror reifies their image. They remain captive to their misperceptions, and thus captive to their poverty.

Some mirrors in the film are physical, some are human. Hank Bell has mirrors. Mary represents the reflection of his past, and his longing to recover some trace of what he's repressed. But Karin represents his present and his future. And her judgment matters to him. Like the image in Escalante's broken glasses, he sees himself through her eyes, and through those eyes seeks recognition as a certain kind of person. I've already indicated the constant tension between Hank and Karin. She attempts to call him to account, and he resists, often belittling her politics and her perspective with anti-elitist slurs. At a political party, Karin makes a drunken scene, ending with her sarcastic remark, "and I'm proud of ole Hank Bellini..." Hank then physically drags her from the party, scolding her: "you third generation progressive, sitting up at Vassar, getting your fat checks from Daddy...”

Yet, in the end, Hank's recognition of his racial transformation is also the recognition of Karin as his racial Master. His exaggerated masculine attempts to control her perspective don't work. He accepts her point of view and understands that she is the phallus that he sought. By internalizing her voice, he symbolically surrenders his own penis, becomes the pure incarnation of the Law, now signifying white supremacy. Hank Bell's discovery of his racial transformation begins with a beating he receives in the subway from a group of young gangsters. In the wake of his attack and her encounter on the elevator, Hank asks Karin, "what do you think of your little victims of social oppression now?" At first, she demurs. But he cross-examines her until she admits that she meant every word when she defended the young gangsters and when she drunkenly questioned Hank's moral compass.

Hank looks down, thoughtfully: "Something else you said. Old Hank Bellini. Danny Dipace said it too. 'Wassa matter Mr. Bellini, you ashamed of being a wop?' ---My old man was ignorant. He thought the way to be a good American was to change your name. It was always easy for me to explain. My father did it. Now I realize I not only went along with it, I was glad. I was secretly glad my name was Bell rather than Bellini. It was part of getting out of Harlem. Like marrying you."

Karin responds indignantly, "You married me because you loved me." But Hank is silent, his eyes to the ground. This pivotal recognition shifts the course of the narrative. In the courtroom sequence that follows, Hank intentionally throws the case, making sure the three boys can't be convicted of first-degree murder. Despite the premeditation, despite the racist motivation behind the crime, none go to the electric chair. With the words "A lot of people killed your son" the film evades the fact that premeditated murder went unpunished by attempting to situate that murder in the context of contemporary social and urban problems. But this situation cannot conceal the fact that Bell himself was driven less by a search for the truth of the case, than by a search for his own true identity. By allowing the young murders to escape full justice, he signifies his affiliation with his past, as well as his recognition of the compromises that shaped his path to full inclusion. Whiteness was Hank's castration, and the phallus he desired, Karin, was herself a metonym of white desire. At the same time, his newly discovered ethnic loyalty provides the basis for racial injustice against the Puerto Rican community in the form of a color-blind racial liberalism that intentionally ignores the racialized struggles of the city's newest arrivals, in the name of social justice for the children of whiteethnic Americans. Finally, Hank's renewed connection to his father, his family, and his past, through Danny Dipace, provides him with a symbolic compensation for what he'd sacrificed.

Yet the film also leaves one question unanswered: What happens to those left behind in Harlem? Those left out of the symbolic contract of the white republic? In a sense, perhaps the most interesting aspect of this film about race made in 1961 is the almost complete absence of any discussion or significant representation of African Americans. By leaving Blacks out of this discussion of race in America, the film becomes a simulacrum for U.S. social and political policy. At the same time, while Puerto Ricans represented racial others, and their perspective incorporated into the metanarrative of the film, that same perspective is repressed by the film's end, and by the film's acceptance 
of a socially constructed, but seemingly inescapable, normative whiteness.

\section{Conclusion}

Both The Young Savages and "The subversion of the subject" proscribe subservience to socially constructed forms of domination. Both inscribe the inescapability of the Law. It's not that alternatives to these reified forms of domination were unimaginable. Quite the contrary. Both the film and essay reveal their anxiety about the imaginable through their silences. The Young Savages ends with unanswered questions. In particular, what of Zorro and the Horseman? The film represses the concerns of the Puerto Rican community in the name of a racial liberalism that privileges a hollowed-out whiteness. Just as the film's narrative echoes the theoretical arguments in Lacan's paper, both conclude with the reinstatement of a reified social construct (the phallus, whiteness), and in doing so, attempt to repress the perspectives of the colonized and oppressed. Despite the importance of the US civil rights movement in 1961, African Americans don't appear in The Young Savages, and, indeed, the only reference to the Black community comes from Zorro's attack on "the niggers." I've already suggested that Lacan's most obvious unwritten opponent in dialogue was Simone de Beauvoir. But equally important, I suspect that Lacan's reification of the phallus attempts to evade, repress, and silence Frantz Fanon.

Like Lacan, Fanon revises Hegel's dialectic, but from the perspective of colonized desire. The colonized world is the Manichean world. The colonizer (the Master) has stripped the colonized of their culture and left them, instead, a set of impossibly insatiable desires. In particular, the colonized will never receive the Master's recognition. To be colonized is to be "disreputable" by definition. ${ }^{40}$ Trapped by the desire for an Other's desire, yet incapable of achieving satisfaction, the colonized subject is constituted as an absence, a lack. This lack provokes envy. "The gaze that the colonized subject casts at the colonists' sector is a look of lust, a look of envy." 41 At the same time, the totalitarian gaze of the colonizer puts the "colonized subject... in a state of permanent tension," a "muscular tension," that "periodically erupts into bloody fighting between tribes, clans, and individuals." 42 Thus far, Fanon's description of colonization does not much depart from the Lacanian model of domination in "The subversion of the subject." Fanon does add the element of embodiment, with the muscular tension produced by the Master's constant surveillance. And Fanon's description of the colonized subject's envy and tension, would seem to capture something of Zorro and his Horseman. But unlike The Young Savages, and unlike Lacan, Fanon resists reifying domination. Instead, he returns to the Hegelian notion of praxis, but now in an embodied form. Recall that the Slave becomes the instrument of the Master. But through work, the Slave masters the world and so transcends slavery. Like Lacan, Fanon recognizes Hegel's idealism and attempts to correct it. Like Lacan, Fanon argues that language forms subjectivity and enforces the normative order. But Fanon finds that it also provides resources for resistance.

The existence of an armed struggle is indicative that the people are determined to put their faith only in violent methods. The very same people who had it constantly drummed into them that the only language they understood was that of force, now decide to express themselves with force. In fact the colonist has always shown them the path they should follow to liberation. The argument chosen by the colonized was conveyed to them by the colonizer. ${ }^{43}$

The code is the code of the other. But these colonized subjects use it to remake the world. The colonizer attempts to impose the sense that the colonial world is the only one possible. But neither the colonizer, nor Lacan, recognize the resistance they enable.

The work of the colonist is to make even dreams of liberty impossible for the colonized. The work of the colonized is to imagine every possible method for annihilating the colonist. On the logical plane, the Manichaeanism of the colonist produces the Manichaenism of the colonized. ${ }^{44}$

If the phallus represents the whiteness of the colonizer, the machete, or the switchblade knife, has the potential to cut through those fabrications. The colonized subject, lost in envy and servitude, comes to recognize its new identity through action, through force, and through violence. Violence unifies the colonized into a new people. Moreoever,

...violence is a cleansing force. It rids the colonized of their inferiority complex, of their passive and despairing attitude. It emboldens them, and restores their self-confidence....Violence hoists the people up to the level of the leader. ${ }^{46}$ 
For Lacan, the normative subject recognizes its castration, and therefore its dependence upon a phallic Law. For Fanon, through embodied force, the empowered subject overthrows the Law and establishes a new order where the "people" become the Law. In this description of Fanon's work, I do not mean to advocate for or against his argument. Instead, I am suggesting that this argument is the hidden subtext of both Lacan's "The subversion of the subject" and the film The Young Savages. Both the essay and the film attempt to "make even dreams of liberty impossible for the colonized," because both the essay and the film feared the alternative.

\section{Endnotes}

1. Author's Note: The following essay represents an expanded version of an argument from Graham Cassano, "Savage Whiteness: The dialectic of racial desire in 'The Young Savages' (1961)," in Delia Konzett (ed.), Hollywood at the Intersection of Race and Identity (Rutgers University Press, 2019). The author wishes to thank Delia Konzett for her editorial comments and Dan Krier for encouraging the publication of this paper in its present form.

2. David Roediger, Working Toward Whiteness: How America's Immigrants Became White (New York: Basic Books, 2005), 11.

3. David Roediger, 'Afterword: DuBois, Race, and Italian Americans' in Jennifer Guglielmo and Salvatore Salerno (eds.), Are Italians White? How Race is Made in America (New York and London: Routledge, 2003), 260.

4. Roediger, Working Toward Whiteness, 57-133.

5. Graham Cassano, A New Kind of Public: Community, Solidarity, and Political Economy in New Deal Cinema, 1935-1948 (Chicago: Haymarket Press, 2015).

6. Jacques Lacan, 'The subversion of the subject and dialectic of desire in the Freudian unconscious,' pp.292325 in Ecrits: A Selection, trans. Alan Sheridan (New York: Norton, 1977).

7. See also Graham Cassano, "Critical Pragmatism's Status Wage and the Standpoint of the Stranger," pp.217-239 in Daniel Krier and Mark P. Worrell (eds.) Capitalism's Future: Alienation, Emancipation, and Critique (Chicago: Haymarket Press, 2017).

8. Charles Horton Cooley, Human Nature and the Social Order (New York: Charles Scribner, 1902), 151. It is worth noting that despite the fact Cooley uses "his mother" as an example in the passage, he does not assign a value to the "correlative sense of" she.

9. Alexandre Kojeve, Introduction to the Reading of Hegel: Lectures on The Phenomenology of Spirit, trans. James H. Nichols, Jr (Ithaca: Cornell University Press, 1969), 5.

10. Kojeve, p.6.
11. Kojeve, p.9. Here Kojeve anticipates (and influences) Lacan's mirror-stage argument. If the imaginary might be recognition by another, then Lacan's symbolic nomdu-pere is recognition "by all others."

12. G.W.F. Hegel, Phenomenology of Spirit, trans. J.N. Findlay (Oxford, U.K.: Oxford University Press, 1977), 111-119.

13. Kojeve, p.10.

14. Kojeve, p.16.

15. Ibid.

16. Kojeve, p.18.

17. Kojeve, p.21.

18. Kojeve, p.23.

19. Lacan, 296

20. Lacan, 297

21. Lacan, 301.

22. Lacan, 302

23. Sigmund Freud, Group Psychology and the Analysis of the Ego, trans. James Strachey (New York: Norton, 1989), 46.

24. Freud, 47.

25. Lacan, 304.

26. Lacan, 305.

27. Emile Durkheim, The Rules of Sociological Method, trans. W.D. Halls (New York: Free Press, 1982), 50-51.

28. Lacan, 310.

29. Lacan, 310.

30. Lacan, 308. 
31. Simone de Beauvoir, The Second Sex, trans. Constance Borde and Sheila Malovany Chevallier (New York: Alfred A. Knopf, 2009), 52-53.

32. Lacan, 311

33. Lacan, 310, 318.

34. Lacan, 320

35. Lacan, 319.

36. Lacan, 324.

37. Lacan, 305.

38. Lacan, 312

39. Frantz Fanon, The Wretched of the Earth, trans. Richard Philcox (New York: Grove, 2004), 6-7; while Lacan may not have had the occasion to read Fanon's last work (published in 1961) before composing his paper, many of Fanon's arguments were introduced, first, in Black Skin White Masks, trans. Richard Philcox (New York: Grove, 2008), originally published 1952.
40. Fanon, The Wretched of the Earth, 4 .

41. Fanon, The Wretched of the Earth, 5.

42. Fanon, The Wretched of the Earth,16-17.

43. Fanon, The Wretched of the Earth, 42.

44. Fanon, The Wretched of the Earth, 50.

45. Fanon, The Wretched of the Earth, 50-51.

46. Fanon, The Wretched of the Earth, 51. 